\title{
Processes and driving forces in changing cultural landscapes across Europe
}

Bürgi, Matthias; Bieling, Claudia; Von Hackwitz, Kim; Kizos, Thanasis; Lieskovský, Juraj;

Martín, María García; McCarthy, Sarah; Müller, Matthias; Palang, Hannes; Plieninger, Tobias; Printsmann, Anu

Published in:

Landscape Ecology

DOI:

10.1007/s10980-017-0513-z

Publication date:

2017

Document version

Publisher's PDF, also known as Version of record

Document license:

CC BY

Citation for published version (APA):

Bürgi, M., Bieling, C., Von Hackwitz, K., Kizos, T., Lieskovský, J., Martín, M. G., McCarthy, S., Müller, M., Palang, H., Plieninger, T., \& Printsmann, A. (2017). Processes and driving forces in changing cultural landscapes across Europe. Landscape Ecology, 32(11), 2097-2112. https://doi.org/10.1007/s10980-017-0513-z 


\title{
Processes and driving forces in changing cultural landscapes across Europe
}

\author{
Matthias Bürgi 1 • Claudia Bieling • Kim von Hackwitz • Thanasis Kizos • \\ Juraj Lieskovský • María García Martín • Sarah McCarthy • Matthias Müller • \\ Hannes Palang · Tobias Plieninger • Anu Printsmann
}

Received: 14 September 2016/ Accepted: 31 March 2017

(C) The Author(s) 2017. This article is an open access publication

\begin{abstract}
Context Cultural landscapes evolve over time. However, the rate and direction of change might not be in line with societal needs and more information on the forces driving these changes are therefore needed.

Objectives Filling the gap between single case studies and meta-analyses, we present a comparative study of landscape changes and their driving forces based in six regions across Europe conducted using a consistent method.

Methods A LULC analysis based on historical and contemporary maps from the nineteenth and twentieth
\end{abstract}

M. Bürgi $(\varangle) \cdot$ M. Müller

Research Unit Landscape Dynamics, Swiss Federal Research Institute WSL, 8903 Birmensdorf, Switzerland e-mail: matthias.buergi@wsl.ch

\section{Bieling}

Societal Transition and Agriculture (430b), Institute of Social Sciences in Agriculture, University of Hohenheim, 70599 Stuttgart, Germany

K. von Hackwitz

Department of Archaeology and Ancient History, Uppsala University, Box 626, 75126 Uppsala, Sweden

T. Kizos

Department of Geography, University of the Aegean, University Hill, 81100 Mytilene, Greece

J. Lieskovský

Institute of Landscape Ecology, Slovak Academy of

Sciences, Akademická 2, 94910 Nitra, Slovak Republic century was combined with oral history interviews to learn more about perceived landscape changes, and remembered driving forces. Land cover and landscape changes were analysed regarding change, conversions and processes. For all case study areas, narratives on mapped land cover change, perceived landscape changes and driving forces were compiled.

Results Despite a very high diversity in extent, direction and rates of change, a few dominant processes and widespread factors driving the changes could be identified in the six case study areas, i.e. access and infrastructure, political shifts, labor market,

\author{
M. G. Martín \\ Nature Conservation and Landscape Ecology, University \\ of Freiburg, 79106 Freiburg, Germany \\ S. McCarthy \\ Landscape Research Group Ltd, \\ PO Box 1482, Oxford OX4 9DN, UK \\ H. Palang · A. Printsmann \\ Centre for Landscape and Culture, School of Humanities, \\ Tallinn University, 10120 Tallinn, Estonia \\ T. Plieninger \\ Department of Geosciences and Natural Resource \\ Management, University of Copenhagen, Rolighedsvej \\ 23, 1958 Frederiksberg C, Denmark
}


technological innovations, and for the more recent period climate change.

Conclusions Grasping peoples' perception supplements the analyses of mapped land use and land cover changes and allows to address perceived landscape changes. The list of driving forces determined to be most relevant shows clear limits in predictability: Whereas changes triggered by infrastructural developments might be comparatively easy to model, political developments cannot be foreseen but might, nevertheless, leave major marks in the landscape.

Keywords Land change science - Landscape history · Oral history interviews · Topographic maps . Land cover change $\cdot$ Technology $\cdot$ Subsidies . Infrastructure

\section{Introduction}

In many parts of the world, landscapes are being transformed at an unprecedented rate, often with negative outcomes for biodiversity and human wellbeing (Antrop 2000; Steiner 2016). As a consequence, in some of these regions, there is a societal demand to limit the rate of landscape change and to direct it in more desirable pathways. Insights into the causes of changes as well as information about impeding and stabilizing factors are therefore needed (Patru-Stupariu et al. 2016).

In recent years, land change science has reacted to this demand by shifting from documenting land cover and landscape change to trying to understand the forces behind the detected changes, i.e. from a descriptive to an analytical approach. The study of the so-called driving forces of landscape change has been promoted and influenced by various methodological contributions (Geist and Lambin 2002; Bürgi et al. 2004; Plieninger et al. 2016), building on a long tradition in geography and landscape research (Wood and Handley 2001). Already Wirth (1969) asked for a "general cultural-geographic theory of forces" and distinguished between economic (e.g. costs of transport), social (e.g. norms, traditions), and public (e.g. policy, planning) forces. More than 25 years ago, Kates et al. (1990) concluded as the key lesson drawn from the papers collected in the volume The earth as transformed by human action (Turner et al. 1990) that a general theory of human-environment relationships would have to conceptualize the relationship between the driving forces of human-induced landscape change, mitigating processes and activities. Driving forces thus form a complex system of dependences, interactions and feedback loops and affect several temporal and spatial levels. Consequently, it is challenging to analyze and represent them systematically, contributing to the recently-lamented lack of clarity and consistency in the terminology used in land change science (Meyfroidt 2015). Contributing further to the terminological tangle are the diversity of spatial and systemic scales in which the different studies work, as well as the absence of a disciplinary home (Magliocca et al. 2015). However, these characteristics should not be seen purely as limitations but also as reflections of the vibrancy of the field.

Three different approaches in studies of driving forces of landscape change can be observed: Case studies conducted at the local/regional scale (Baumann et al. 2011; Bürgi et al. 2015), large-scale analyses (Terres et al. 2015), and meta-analyses (Munteanu et al. 2014; van Vliet et al. 2015; Plieninger et al. 2016). Whereas local case studies on landscape changes aim at grasping the specifics of a place and its development, which is essential for a systematic understanding of local changes, large-scale analyses search for main trends and processes over large areas. Meta-analyses are motivated by the search for general patterns within the case studies, i.e. constellations of prerequisites which, if combined with a specific set of potential driving forces, result in a somewhat predictable change. Meta-analyses are limited by the diversity of approaches applied and the case studies included (Magliocca et al. 2015). In addition, the distribution of the case-studies found in meta-analyses hardly reflects the diversity of the system under study in a meaningful way, as they were not planned and conducted with the aim of representing a larger area but with specific aims and objectives regarding a particular location or landscape. Any type of synthesis requires standardization and harmonization, and is further impeded by the diversity of disciplines contributing to land change science (Magliocca et al. 2015).

In this paper we set out to address the gap between the single case study approach and meta-analyses. We do this by conducting a comparative study of landscape changes and their driving forces based on 
case studies that have been designed to facilitate a cross-site comparison. Only few such comparative studies have been carried out so far (e.g. Beilin et al. 2014) as major challenges exist regarding the consistency of source availability and diversity of the landuse systems to be considered.

We present results from a comparative study of six case study municipalities (SMs) across Europe, looking at how the European cultural landscape has changed in the course of the last 100 to 150 years. The following questions are addressed: (a) How did the landscapes change? (b) What are the dominant processes and the temporal trends therein? (c) What driving forces are responsible for the changes and processes observed?

Two main methodological challenges are addressed: (i) enabling the maximum degree of comparability between the case-study results, and (ii) addressing a core issue in studies of landscape change in general, which is the fact that the main sources used are maps and various types of remote sensing information. These sources show, foremost, information on land use/land cover (LULC), but not 'the landscape' per se, as for example defined by the European Landscape Convention (ELC 2000), which understands landscape as "an area, as perceived by people, whose character is the result of the action and interaction of natural and/or human factors". We tackle this challenge by applying a mixed-methods approach that provides a cultural, social and political perspective on how inhabitants/stakeholders of those case study landscapes perceive and remember the driving forces of landscape change. By combining quantitative information on land use/land cover derived from topographical maps or aerial photographs with qualitative information from oral history interviews, we stand in the research tradition of linking remote sensing information with social science approaches (Rindfuss and Stern 1998) in order to gain a comprehensive understanding of land change (Sooväli et al. 2003; Rindfuss et al. 2004; Young et al. 2006; Yaeger and Steiger 2013).

\section{Material}

This study has been conducted in a series of case study areas, determined in the EU FP7 project HERCULES (http://www.hercules-landscapes.eu/). The study areas span major environmental and land-use history gradients throughout Europe (Table 1, Fig. 1), and they cover the main types of transition in European land management regimes as described by Rudbeck Jepsen et al. (2015). By choosing municipalities as the spatial entities of analysis, we have a better means of integrating statistical information as well as clear boundaries of reference for linking information gained in interviews to that from land cover data. The size of the study municipalities (SMs) ranged from 24 to $208 \mathrm{~km}^{2}$ (Table 1). All information on case study areas has been contributed by coordinators who are familiar with local conditions in each SM.

The main data sources for studying LULC changes were topographical maps or aerial photographs from the 19th and 20th centuries. Compiling comparable LULC data across many different regions and across time, based on highly heterogeneous historical and contemporary topographical maps is, however, very challenging. The case study coordinators compiled lists of potentially suitable maps based on archival work which allowed to come up with a set of historical and contemporary topographical maps with sufficient mapping quality and thematic resolution for all SMs. Overall, LULC was assessed for 28 time stages (Fig. 2), which corresponds to an average number of 4-5 stages per SM. For five time stages, aerial pictures were included, as no suitable maps were available (indicated by dotted boxes in Fig. 2).

Using a mixed-methods approach that integrates quantitative and qualitative information requires the synthesis of qualitative information according to the standards of social sciences-in this case, specifically historical sciences-as a prerequisite to link it to the units used in the analyses based on quantitative information. Two types of data for the driving force analysis were provided by the case study coordinators for every SM. On one hand, so-called timelines were assembled providing the historical background of the SM based on secondary literature, statistical information and expert knowledge. Timelines included information on important events with potential impact on landscape changes. On the other hand, a series of oral history interviews (OHI) was carried out to complement the LULC information derived from the map analyses with information on perceived and remembered landscape changes in the SM and to gain additional information on the driving forces of landscape change. 
Table 1 The characteristics of study landscapes and the study municipalities (SM) selected

\begin{tabular}{lllcll}
\hline $\begin{array}{l}\text { No in } \\
\text { Fig. } 1\end{array}$ & Country & Study municipality & Area $\left(\mathrm{km}^{2}\right)$ & $\begin{array}{l}\text { Approx. } \\
\text { population- } \\
\text { density } \\
\left(\mathrm{p} / \mathrm{km}^{2}\right)\end{array}$ & Main landscape character \\
\hline 1 & Sweden & Börje & 47 & 20 & Rural tableland with suburban aspects \\
2 & Estonia & Alatskivi and Peipsiääre & 160 & 12 & Rural drumlin fields adjacent to large lake \\
3 & Great Britain & Modbury & 24 & 60 & Rural tableland \\
4 & Switzerland & Lenk & 123 & 19 & Rural touristic alpine valley \\
5 & Spain & Colmenar Viejo & 184 & 247 & Mountain range adjacent to metropolitan area \\
6 & Greece & Plomari and Gera & 208 & 44 & Volcanic Mediterranean island \\
\hline
\end{tabular}

Fig. 1 Location of the study municipalities (SMs) across Europe (1. Börje, 2. Alatskivi and Peipsiääre, 3. Modbury, 4. Lenk, 5. Colmenar Viejo, 6. Plomari and Gera)

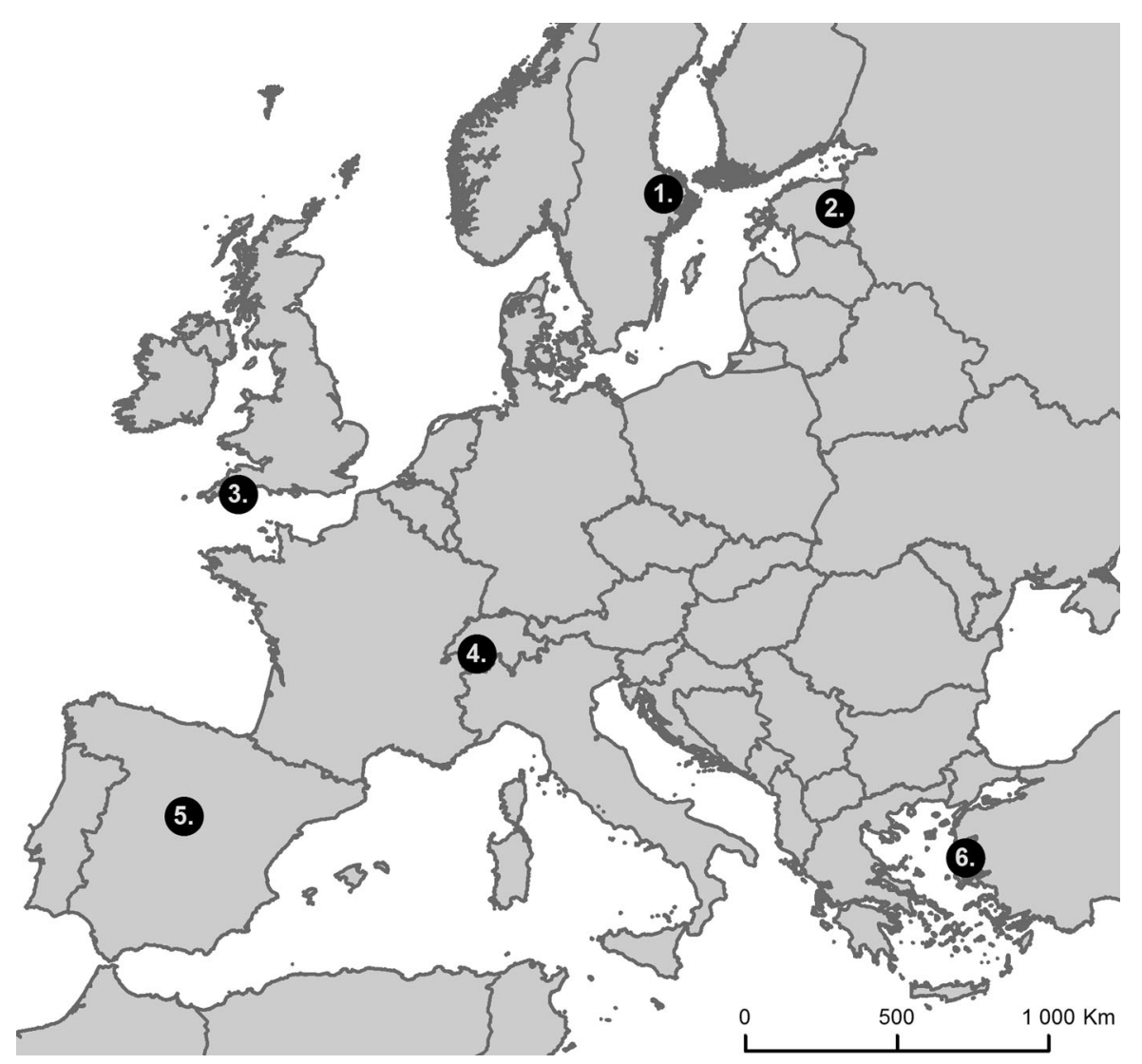

A total of 50 interviews was conducted for the SMs, which corresponds to an average of 8.3 interviews per SM (minimum six, maximum fourteen), a number which is slightly below the recommended number of ten oral history interviews for the detection of local pattern e.g. in land use (Wierling 2003). Due to the convergence of responses, we consider the number of interviews to be adequate for the targeted information; moreover the number of potential elderly interviewees is always limited. To achieve comparable levels of generalization on both sides of the disciplinary divide, we compiled short narratives on the LULC results as 


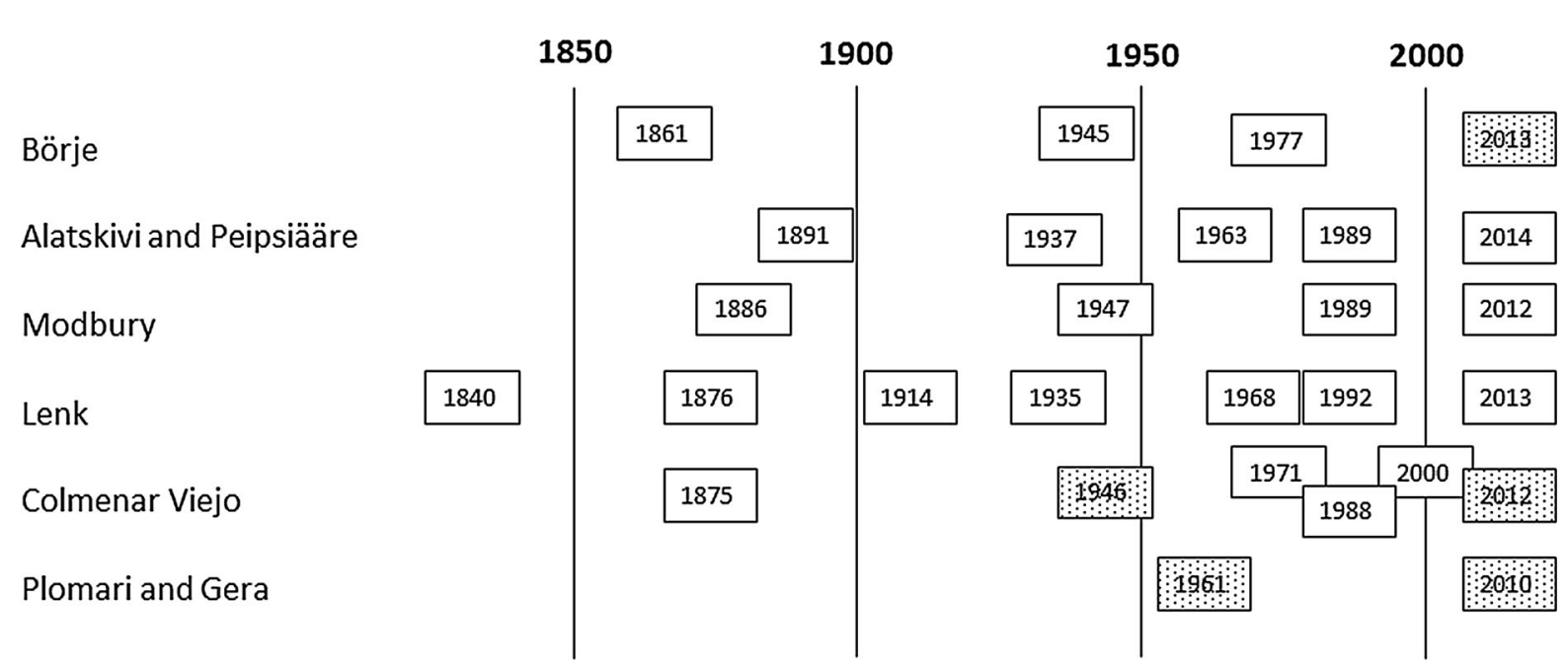

Fig. 2 Distribution of historical maps (blank boxes) and aerial photographs (dotted boxes) for assessing LULC changes in the six SMs considered

well as the information on main driving forces provided by the OHIs and the timelines of local developments.

\section{Methods}

All historical maps were scanned and georeferenced. To ensure optimum comparability, a common scale of 1:50,000 was adopted for the digitalization process and a common legend for the six SMs was developed. To ensure maximum comparability, but at the same time allow the inclusion of more detailed information if available for specific SMs, we developed a scaled legend, including two levels of LULC categories. The LULC categories determined on level one were settlement, cropland, grassland, forest, wetland, water, and bare land. The diversity of real world situation represented in one of the classes differs greatly with a clear focus on land cover-the class grassland for example includes natural grasslands as well as meadows and pastures, as the maps do not allow to differentiate between the related land uses. On level two, SM-specific LULC classes, such as olive plantation or glacier, were added.

To minimize the spatial inaccuracy errors, the time layers were digitized regressively, i.e. the current and most precise layer was digitised first and, in the older maps, boundaries were re-drawn only if a change was clearly documented and evident (Feranec et al. 2007; Bednarczyk et al. 2016).

For the purposes of this paper we distinguish between changes (in LULC proportion), conversions (between LULC classes), overarching processes and driving forces. Based on the map analyses, changes in LULC for all SMs were determined first. Persistence in LULC (sensu Patru-Stupariu et al. 2016) was also analysed, but will be presented in a separate paper (Lieskovský J, Bürgi M (submitted)) as the questions addressed here are all focusing on change. We then calculated the conversions, i.e. specific one-directional changes between two LULC categories, by map overlay. All areas converted were categorised according to the type of conversion occurring in a given period. To ensure comparability over time, mean yearly rates of conversion were calculated by dividing the total area affected by a specific type of conversion, by the length of the individual period. To enable comparison of conversion rates between different $\mathrm{SMs}$, the values were normalized to a size of $100 \mathrm{~km}^{2}$ As a measure of the overall landscape dynamics in a $\mathrm{SM}$, all conversions were summed up, resulting in an overall annual conversion rate per $100 \mathrm{~km}^{2}$ for all SM.

The term 'processes' is used in this paper to refer to overarching trends, which are calculated based on the conversions. For example, all conversions of any type of LULC class into settlement were added up to provide a total figure for the process entitled settlement 
growth. Other processes were abandonment, expansion of agriculture, deforestation, afforestation, extensification of agriculture, intensification of agriculture, disturbance/rockfall/other (i.e. all conversions to the LULC class bare land), re-wetting, flooding, siltingup and drainage. Table 2 shows which conversions contributed to these different processes. The same conversion can contribute to different processes: if forests have been converted into settlements, this area is not only part of the process settlement growth but at the same time, feeds into the process deforestation. We are aware that what is called processes in this study has been called proximate drivers in other studies, e.g. by Geist and Lambin (2002), who distinguish between proximate causes/drivers and underlying driving forces. However, we prefer to reserve the term driving forces to factors which have contributed to changes in the landscape, rather than using it also for aspects of the changes itself.

This definition of processes allows us to synthesize the LULC conversions into entities, upon which driving forces act, such as settlement growth, which is driven by the demand for housing - a demand which is not related to a specific conversion type, as settlements will as likely expand on cropland as on grassland.

For synthesizing information on dominant processes across all SMs, the different dates represented in the available maps were taken into account, by dividing the whole study period into six 25-year periods (from 1850 to 2000) and one last 12-year period. The processes determined were ranked per SM based on the area affected and assigned to the corresponding 25-year (resp. the 12-year) study period. Rank sums for all SMs and all periods were calculated and the most important processes across all SMs determined.

To collect, analyse, and disseminate oral histories is a popular research tool in the humanities and social sciences, and especially long-term residents of a landscape are valuable "living repositories of information on earth and water resources" (Fogerty 2001). Consequently, oral history has developed into an important research tool of land change science and landscape ecology (Marcucci 2000; Bürgi and Gimmi 2007; Rhemtulla and Mladenoff 2007). Following the common assumption that elders within a local community are able to provide most insights into the local knowledge system (Davis and Wagner 2003), the interviewees were selected based on their age and ability to adequately represent the diversity of roles in, and perspectives on, the landscape, such as farmers, foresters, teachers, community officials, ordinary people and local historians. An equal representation of gender was aimed at, resulting in 29 interviews conducted with men and 21 with women.

The first short narrative summarized the changes in LULC as seen in the map analysis. Whereas the

Table 2 The term "processes" is used in this paper for overarching trends, which are calculated based on the changes

\begin{tabular}{|c|c|c|c|c|c|c|c|}
\hline & Settlement & Cropland & Grassland & Forest & Wetland & Water & Bare land \\
\hline Settlement & & - & - & - & - & - & - \\
\hline Cropland & Settlement growth & & Extensification & $\begin{array}{l}\text { Afforestation/ } \\
\text { succession }\end{array}$ & Re-wetting & Flooding & e.g. Rockfall \\
\hline Grassland & Settlement growth & Intensification & & $\begin{array}{l}\text { Afforestation/ } \\
\text { succession }\end{array}$ & Re-wetting & Flooding & e.g. Rockfall \\
\hline Forests & $\begin{array}{l}\text { Settlement growth/ } \\
\text { deforestation }\end{array}$ & $\begin{array}{r}\text { Intensification/ } \\
\text { deforestation }\end{array}$ & Deforestation & & Re-wetting & Flooding & e.g. Rockfall \\
\hline Wetland & $\begin{array}{l}\text { Settlement growth/ } \\
\text { drainage }\end{array}$ & $\begin{array}{l}\text { Intensification/ } \\
\text { drainage }\end{array}$ & Drainage & $\begin{array}{l}\text { Drainage/ } \\
\text { afforestation }\end{array}$ & & Flooding & e.g. Rockfall \\
\hline Water & $\begin{array}{l}\text { Settlement growth/ } \\
\text { drainage }\end{array}$ & $\begin{array}{l}\text { Intensification/ } \\
\text { drainage }\end{array}$ & Drainage & $\begin{array}{l}\text { Drainage/ } \\
\text { afforestation }\end{array}$ & Silting-up & & - \\
\hline Bare land & Settlement growth & Intensification & Succession & Afforestation & Re-wetting & Flooding & - \\
\hline
\end{tabular}

The changes therefore can contribute to different processes, e.g. the conversion of forests into settlements contributes to the two processes urbanization and deforestation. Intensification and extensification refer to changes in agriculture 
common legend allows comparison across SMs, it does at the same time hide much of the specifics and dynamics at the local level. This first narrative therefore not only includes the information collected in legend level one but also the more detailed legend level two. The OHIs contain information about the perceived and remembered landscape change, resulting in a second, complementary narrative on the perceived landscape change, covering roughly the last two or three 25-year periods depending on the knowledge and memory of the respondents. The timelines of local development, together with the OHIs, provide information on likely driving forces behind the conversions and processes observed in the maps, which were also summarized in short narratives.

\section{Results}

\section{Changes and conversions}

The overview of LULC changes per SM (Fig. 3) reveals major differences in dominant land cover classes between the SMs. The cover classes of settlement, grassland and forest were occurring in all SMs and in all time periods. Settlements increased always and everywhere, but in very different proportions ranging from less than $1 \%$ of the total area being covered by buildings in Lenk to more than $10 \%$ in Alatskivi and Peipsiääre. Forests showed the most predominant increase apart from in Börje, where there was no net increase at all. On the other hand, wetlands, if mapped, almost always declined.

Overall, Colmenar Viejo was the fastest changing SM (38.76 ha/y - all values normalized to a size of $100 \mathrm{~km}^{2}$ ), followed by Plomari and Gera (35.61 ha/y) and Alatskivi and Peipsiääre (29.26 ha/y). Börje showed about half as much change (16.76 ha/y), and Lenk even less (11.43 ha/y). Modbury (5.37 ha/y) was the most stable among all the SMs included in the study.

The highest rates of change in any of the time periods (Fig. 4) were recorded in Colmenar Viejo for two relatively short periods; $1971-1988$ (77.10 ha/y) and 1988-2000 (69.45 ha/y) as well as during the much longer period 1875-1946 (66.73 ha/y). This was followed by Alatskivi and Peipsiääre during 1937-1963 (60.37 ha/y). For Plomari and Gera, only one period, 1961-2010, was assessed (35.61 ha/y). The period of fastest change in Lenk was 1935-1968
( $29.80 \mathrm{ha} / \mathrm{y})$, but similar rates were recorded for the nineteenth century, (21.88 ha/y in 1840-1876). The least dynamic periods, on the other hand, were recorded for Lenk in 1992-2013 (2.68 ha/y) and 1876-1914 (2.77 ha/y), Colmenar Viejo 1946-1971 (5.65 ha/y), and Modbury 1886-1947 (5.89 ha/y). It is interesting that in none of the SMs did the latest period assessed show the highest rates of change; it was even the least dynamic period for Lenk.

The conversion of cropland to grassland was the most dominant land cover conversion (data not shown), being especially prominent in Colmenar Viejo, and Plomari and Gera. The expansion of forests on cropland and on grassland were second and third most important, followed by the reverse trend, i.e. forest to cropland, and grassland to cropland. Whereas some conversions were ranked among the five most important in almost all SMs (such as cropland to grassland, forest to cropland, grassland to cropland, and cropland to settlement), others were foremost of local importance, such as the conversion of wetland into forest in Alatskivi and Peipsiääre.

\section{Processes}

The rank sum of processes across all SMs and periods revealed abandonment to be the most important (rank sum 117), with a slight tendency to increase from the 1950s onwards (Fig. 5). The second most important process was afforestation (rank sum 76), which exceeded deforestation (rank sum 62). However, whereas deforestation showed similar values throughout the study periods (despite fewer SMs reporting in the nineteenth century), afforestation reached higher values since the period 1925-1950. Expansion of agriculture (rank sum 70) and intensification of agriculture (rank sum 63) were also important processes, the latter with a strong decreasing trend. For extensification of agriculture (rank sum 53), we saw an increase from the 1950s. Settlement growth (rank sum 41) showed an overall increase since 1850 and a peak in the last period 2000-2012.

If we start from the past, we see that, of the three most prominent processes in the late nineteenth century, abandonment and afforestation, remained important throughout the study period, while intensification of agriculture significantly lost its importance, and was replaced by settlement growth and extensification of agriculture, which are now at a very similar 

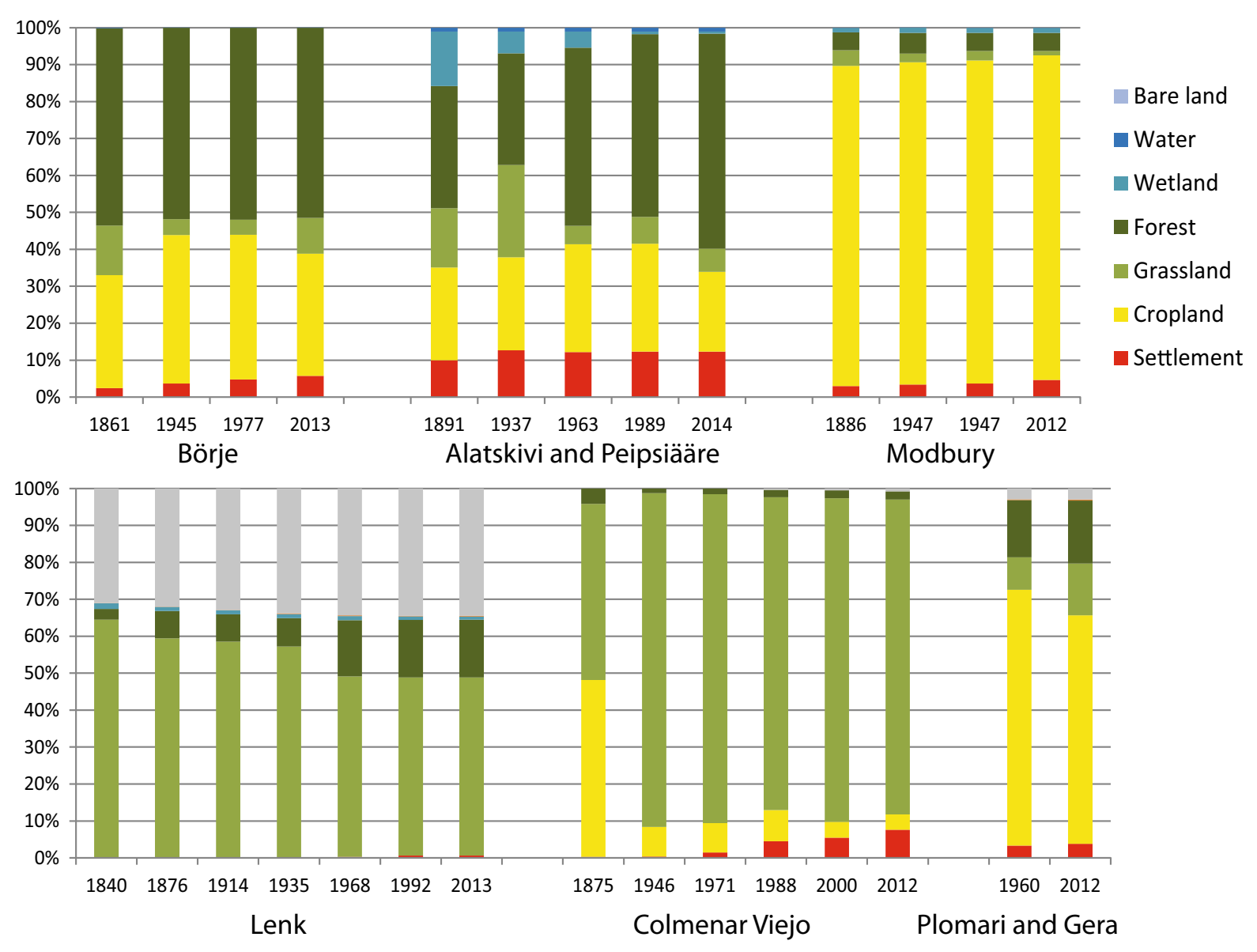

Fig. 3 Land cover changes in the six study municipalities assessed

Fig. 4 Rates of change the six study municipalities assessed (data normalized to a size of $100 \mathrm{~km}^{2}$ )

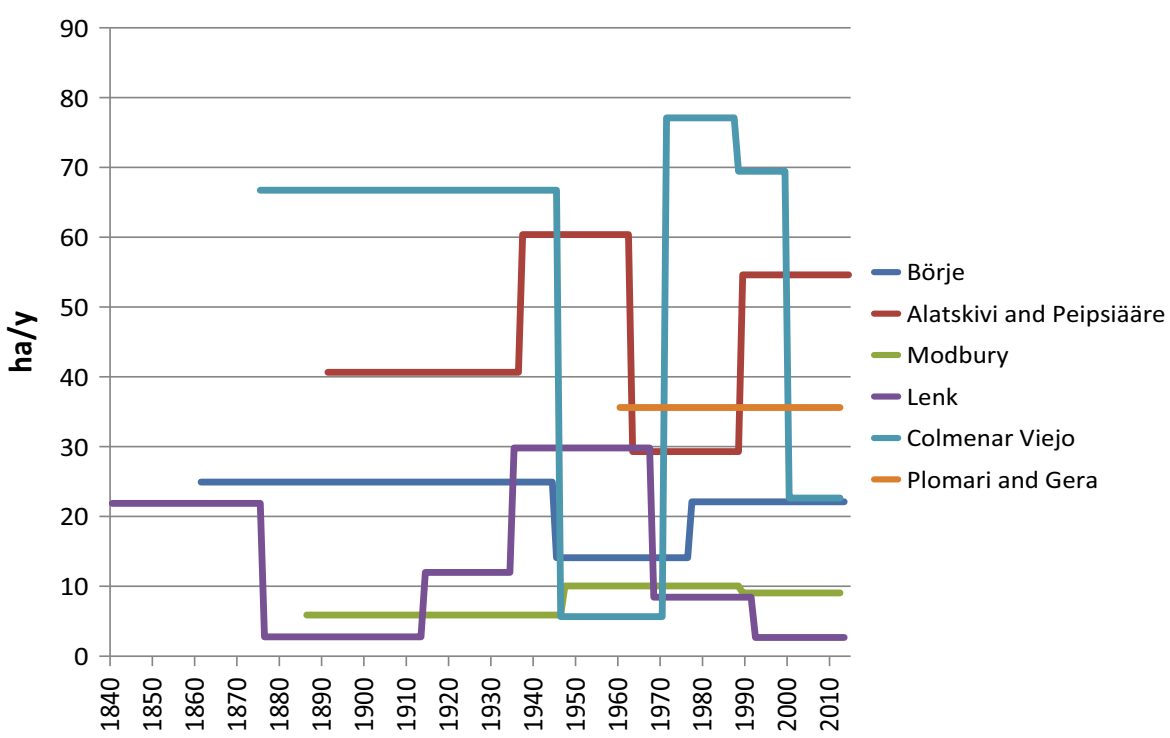


Fig. 5 Importance of processes of landscape change across all SMs. To take the different number of SMs reporting per period into account, average ranks per period and per SMs reporting were built for the major processes. No linear development between the points is assumed

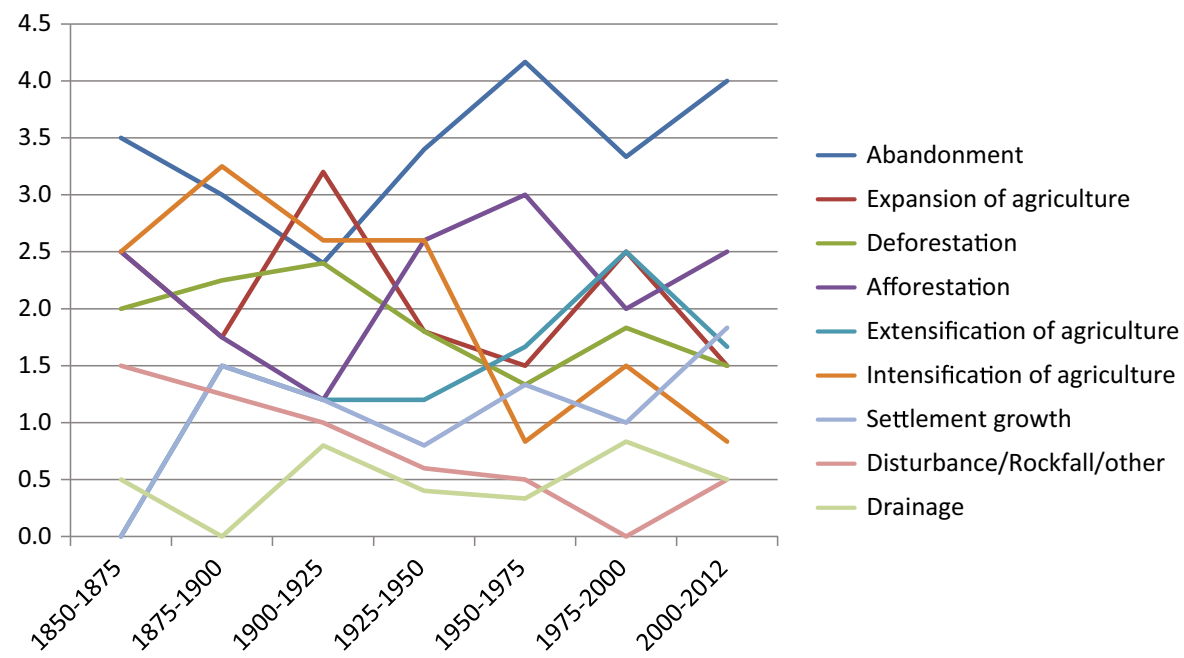

level (Fig. 5). Thus, the real long-term shift in processes is the replacement of intensification of agriculture by its reverse, i.e. extensification of agriculture, paralleled by an increase in settlement growth.

Recorded and perceived changes, and the related driving forces

\section{Börje}

LULC: The LULC changes recorded for Börje were moderate compared to the other SMs. From 1861 to 1945, an intermediate increase in cropland was recorded, mostly due to seasonal agriculture expanding onto grasslands, but also onto forest land (Fig. 3). After little further change between 1945 and 1977, the trend reversed, i.e. seasonal agriculture declined, mostly reverting to grassland and, to a smaller degree, into settlements. Settlements increased from 2.4 to $5.7 \%$ over the whole study period.

Perceived landscape change: The interviewees reported minor changes, mostly due to larger farm units and new houses being inhabited by town people. Moreover, they report a shift from pigs/dairy cows to beef cattle and horses, the spread of monocultures, a reduction in summer grazing and more traffic overall.

Driving forces: During the period from 1861 to 1945, emigration due to harvest failures and employment opportunities in industry resulted in a population decline. The remaining agriculture was intensified (expansion of cropland on grassland), which however was an intermediate phenomenon, as abandonment and settlement growth became the dominant processes after 1945. The increase in average farm size, and the abandonment of dairy farming, paralleled by a concentration on wheat production on cropland and on horses (probably mostly for leisure purposes) represents profound remodeling of the agricultural sector, shaped by the respective national and EUlegislation: Being a milk farmer is not productive anymore so they all trade it for crops. The milk is getting cheaper and cheaper. The further expansion of settlements is well explained by the proximity to the city of Uppsala and the increase in commuting by car.

\section{Alatskivi and Peipsiääre}

LULC: The overall rate of change in this SM was about twice as high as in Börje. From 1891 to 1963, wetlands declined from 15 to $4 \%$, mostly going into meadows and pastures as well as into wooded grasslands and shrubs, and between 1963 and 1989, wetlands disappeared almost completely. From 1937 to 1963, dry forests expanded massively, partly on meadows and pastures, but also on areas formerly covered by wet forests and seasonal agriculture. The period from 1989 was characterized by an expansion of dry forests (reaching 52\% cover in 2014), mostly on areas which had earlier been used for seasonal agriculture.

Perceived landscape change: Above all, people reported a massive expansion of forest onto former agricultural land: Like in medieval times-all bushes and trees. Also the coastal landscape changed 
significantly: We didn't have so much reed, the coast was clear. My Mom remembers when it was absolutely clear. In addition, linear elements were straightened (In childhood the roads were more curvy and constructed to suitable places. During the Soviet period some were straightened.) and point elements, such as trees, disappeared (And we used to have a lot of big trees. During the Soviet period they were registered as landmarks for orientation for fishermen on the lake.).

Driving forces: From 1891 to 1963, estates were converted into smaller farming units, which later were organized into large collective farm units, i.e. the Kolkhozes: Kolkhozes took everything. People without land were then happy. Those who had to give up their lands, they suffered. Most of the drainage projects might have been conducted as part of the expansion and intensification projects of these Kolkhozes. From 1937 to 1963, the organization of agriculture in large-scale land units supported the twofold development evident in this period: The intensification of better lands on the one hand and the abandonment/conversion into forests of less profitable areas on the other. 1991 brought the end of Soviet occupation and a sharp decline in agricultural activities: If you are native you can see the waste of the land into bush land and forest but old people don't have the strength to clean it. ... we have a very tender relation to the land because our ancestors, our garden beds, ...The last ones, like mammoths as our children don't like to work like that. They know that they can earn money more easily. Thus, younger people have moved to the city and the elderly people left behind are not able to do all the work to keep the landscape open.

\section{Modbury}

LULC: Overall, Modbury experienced very few LULC changes. On a rather small scale, grasslands were converted into crop rotation land, i.e. the by far most dominant and overall very stable land cover type, covering $86 \%$ in 1947 . This trend was continued in the subsequent periods, but also the reverse trend, i.e. the conversion of cropland into grassland was observed. Settlements expanded exclusively on cropland from 1947 to 1989 and at an even higher rate from 1989 to 2012, in which period also some grasslands and shrubs were built over.

Perceived landscape change: The interviewees reported more subtle than drastic changes, except for the growth of settlements: There are a tremendous amount of houses that have been built here since the 1970s. Additionally, hedgerows and old orchards disappeared, which is linked to change in sizes of fields, farms and associated herd size, which all went up: To enable you to farm more productively, you tended to want bigger fields. And something else that has changed dramatically in my lifetime is the size of farms. This farm is about 5 or 6 farms all into one now. Changes in crops produced also leave traces in landscape appearance, i.e. from growing crops such as barley, corn, mangles, beet that were primarily used as animal fodder, to now growing other, non-fodder crops. And linseed, we grow a lot of linseed. That turns the fields blue. Additionally, the soundscape has changed due to decreasing wildlife: You don't hear so many skylarks, especially in the arable where they use a lot of sprays. So you are losing a bit of that I think.

Driving forces: Many changes reported are on the level of land use, i.e. due to changes in agriculture. The interviewees put many of the changes down to government programs, such as the Agriculture Act of 1947 which focused on food production by guaranteeing prices for farm products (...there was a push wasn't there to produce things and we had a ploughing up subsidy - to plough up and for crops.), but also afforestation, subsequent subsidies for farm improvement from the 1960s onwards, and measures to eliminate tuberculosis (resulting in the need to pasteurize the milk). But, the interviewees also recognize the role of the individual farmer: Government subsidies make a vast amount of difference. ...Well on the one side it's individual actors.

Economic pressures have triggered a general need to grow and to intensify farming. Fewer farmers on larger farms are now working the land: Because of the economic needs to make that more efficient, more effective, the farms have lost their small dairy herds to be one large dairy herd, The agricultural side I won't say has collapsed, labour wise it has collapsed. Additionally, they use larger machinery, the use of which is made easier by removing features such as hedgerows, or enlarging entrances into: And you want bigger machinery, so land changes.

Lenk

LULC: Comparatively low rates of change are reported for this SM. Meadows and pastures, covering 
$64 \%$ in 1840 , declined to $55 \%$ in 1935 and $48 \%$ in 1968. Most of this area changed into forests or became covered by rocks and stones i.e. converted to bare land. The increase in forest area was most pronounced from $1935(8 \%)$ to 1968 (15\%), after which it was relatively stable. After a stable period from 1840 $(14 \%)$ to $1935(13 \%)$, the area covered by glaciers declined quite dramatically to $10 \%$ (1968) and $8 \%$ (2013). However, this change did not show up on legend level 1 (Fig. 3), as the areas of former glaciers for the most part turned into natural rock (increasing from 17 to 27\%), and both categories are in the land cover class bare land on legend level one.

Perceived landscape change: There is consensus that, since the 1960s, the construction of secondary homes left major marks in the landscape. Intensification of farming expressed itself in large stables being built near the village, and new roads making alpine pasture areas more accessible. Shifts in the pattern of farming intensity left traces in the land: The cattle are longer in the valley and longer on the alps but only for a shorter period at a middle elevation., ... some land is overgrown with bushes. Farmers cannot look after the whole area anymore and do not farm the steep slopes anymore. The interviewees are very aware of landscape changes due to melting glaciers: You don't see the glaciers from down here. The glaciers are melting fast.

Driving forces: Weather- and pest-induced crop failures, and an increasing competition from lowland cheese factories made the economic situation difficult, triggering emigration and a population decline from 2393 in 1846 to 1750 in the early decades of the twentieth century. This might have reduced the available workforce for maintaining pastures and meadows, i.e. removing of bushes and young trees, but also of debris coming down from the rocky slopes. This neglect is the likely cause of pastures turning into forests or into the land cover class natural rock. After World War II, winter tourism was promoted and second home construction started: Everybody in the village had some benefits from the building industry and so it is impossible to stop it. On the one hand agriculture was intensified, but on the other laborintensive activities, such as wild hay making on steep slopes, were abandoned: Wild hay making was very important before 1945. Wild hay was in demand and one could make money with it. After the war this stopped abruptly. State-guarantees for prices for agricultural products and subsidies for road construction to access alpine pastures and afforestation projects left their marks. In the final period, apart from the melting glaciers, the rates of change slowed. Zoning regulations, a relatively stable economy and ongoing subsidies for agriculture increased persistence in the landscape.

\section{Colmenar Viejo}

LULC: Overall, this SM experienced the most radical changes and the highest rates of change. Between 1875 and 1946, seasonal agricultural land was converted at a high rate into meadows and pastures, which then became overgrown by wooded grasslands and shrubs from 1946 to 1971 (not showing up on legend level one as in Fig. 3). Settlements began to expand after 1946, mostly on meadows and pastures. The decline of meadows and pastures continued after 1971, converting to wooded grasslands and shrubs, but also to seasonal agriculture, which later again reverted to grassland. Between 2000 and 2012, settlements expanded from 5 to $8 \%$ on meadows and pastures as well as on areas of wooded grassland and shrubs.

Perceived landscape change: The interviewees mentioned the abandonment of crop production in the 1960s, and the subsequent conversion of cropland to pasture land. Until the 1950 s, sheep herds were kept for wool production but were replaced by dairy cows until the 1980s, followed by beef cattle. The strong urbanization process, leading to an increase in population, was reflected in completely new settlements and urban areas being built, partly on former quarries: The village has invaded everything.

Driving forces: Between 1875 and 1946, a first period of conversion-from subsistence farming to market-oriented farming-took place and cropland was converted into grassland. Apart from goats and sheep, breeding wild bulls became important. Bulls need pastures but also more nutritious crops and this triggered, in places, an increase in cropland (i.e. a reverse trend to the one mentioned above). People improved grazing grounds by actively removing shrubs and trees: The people of Colmenar Viejo have been big enemies of the trees because they were not useful for grazing. Industrial quarries became established prompting the construction of a railway, on which also milk could be transported easier and more quickly to Madrid's dairy plants, making dairy 
farming more attractive. Wild bull farms decreased after the Spanish Civil War (1936-1939). The decline in dairy cows is said to have been caused by the Common Agricultural Policy (CAP) and the milk quotas. Population increased, and it is likely that an increasing number of people were working in the quarries and the construction sector. Due to the construction of a highway in 1970, the area became much more accessible for people from Madrid, which led to a massive increase in urbanization with second home residences as well as houses for commuters. Quarrying became more mechanized and people started to take jobs in the tertiary sector.

\section{Plomari and Gera}

LULC: This SM also shows quite high rates of change. The dominant conversion types for the only reported period 1961-2010 were the conversion from cropland to forests and grassland, and the reverse, i.e. the conversion of forests to cropland. Forests to grassland, and cropland to settlements, took place to a lesser extent. Overall, the proportion covered by perennial agriculture decreased from 68 to $61 \%$ and wooded grassland and shrubs increased from 8 to $13 \%$ of total land cover, but these net changes hide conversions at high rates going in both directions. These high turnover rates between categories might partly have been caused by difficulties in distinguishing correctly between forests, olive groves (perennial agriculture), and wooded grasslands and shrubs in digitalizing the aerial photographs.

Perceived landscape change: The interviewees report a decline in the number of olive trees from the 1960s and a tendency towards agricultural abandonment and the gradual destruction of terraces for olive trees. The continuing agricultural activity is more mechanized, making the work less time consuming but more hectic.

Driving forces: The statistical numbers reveal a decline in population and numbers of farms, and a small reduction in area covered by olive plantations. Up to the present, rural depopulation is widespread and the younger generations are seeking more profitable employment. Structural challenges, such as the maintenance of labor-intensive terraces for olive cultivations and the limited accessibility due to the rugged terrain, make olive farming even less attractive. The increase in settlement along the coast so far has not left major traces in land cover in the study region.

\section{Discussion}

Changes, conversions and processes

The overall rates of change differ between the SMs by a factor of seven, respectively almost thirty, if the most dynamic and the least dynamic period from all SMs are compared (Fig. 4). Whereas the rates of change are rather stable in some SMs, other SMs show high temporal variability in the rates of change. Interestingly, the rates of change did not increase throughout the study period and, in many cases, the last period even indicates comparatively low rates of change, as e.g. also shown by Schneeberger et al. (2007).

In a pan-European analysis of the twentieth century LULC change, Fuchs et al. (2015) determined land abandonment (cropland to grassland), afforestation and cropland expansion to be the most important landchange processes. A recent review of studies looking at driving forces of landscape change in Europe (Plieninger et al. 2016) similarly determined "land abandonment and agricultural extensification" as the most prominent "proximate driver" (i.e. following the terminology used by Geist and Lambin 2002). Our results fully confirm these findings, as the ranking of conversion types was dominated by the conversion of cropland to grassland, followed by the expansion of forest on cropland and grassland (i.e. afforestation) and the conversion of cropland to grassland.

Based on the small number of SMs included, such a correspondence with pan-European studies and review analyses was not to be expected. Nevertheless, these six SMs do indeed seem to show the most important LULC changes and the related driving forces. What is also evidently captured is the polarization of landscape between intensification and extensification processes. These processes are visible at the level of land cover, where both settlement growth and afforestation processes often take place on former agricultural land but also within the remaining agricultural land, where the processes of intensification (with a downward trendFig. 5) and extensification (showing a upward trendFig. 5) stand for a bi-polar development, as reported also by van Vliet et al. (2015) and by Rudbeck Jepsen et al. (2015). 
What are the main drivers?

The narratives on LULC change based on the map analysis reveal a diversity of developments that is paralleled by the perceived landscape change based on the OHIs. The OHIs also provide input for the subsequent narratives on driving forces. Within these narratives, the four factors fostering landscape change determined by Antrop (2005) appear prominently, i.e. accessibility, urbanization, globalization and calamity. Specifically, access and infrastructure show up as core drivers in almost all narratives: The construction of railways or highways increases accessibility and allows goods to be transported and people to travel-in both directions, i.e. new markets open up for locally produced goods but local goods face competition from goods produced cheaper elsewhere. Similarly, people can start commuting to nearby employment opportunities or second homes become established which breaks up the former, direct linkage between population and land use. Depopulation might happen in parallel with abandonment but abandonment is also possible where there are increasing population numbers, if people are no longer working the land.

Closely connected to the question of accessibility, but important enough to be called separately, job availability, i.e. the labour market, also seems to be a ubiquitous driver: The hardship of traditional farming, be it wild-hay making and pasture maintenance in the Alps, maintaining olive-terraces in the Mediterranean, mangle-hoeing in South Devon or simply agricultural activities on rugged, steep terrain which is hard to intensify, makes farming less profitable, with jobs in the secondary and tertiary sector seeming more attractive, especially to younger people. If accessibility does not allow for commuting to alternative labor markets, rural depopulation takes place, public services are reduced and shops are close: And that's the decline of country life.

What Antrop (2005) calls calamities, becomes well visible in political shifts: The political and economic boundary conditions caused by the period of Soviet occupation in Alatskivi and Peipsiääre or the Spanish Civil War and the subsequent regime of Franco in Colmenar Viejo left their traces on the land-as did the legal homogenization caused by EU legislation and the resulting pressure on local agriculture.
Globalization expresses itself prominently in a series of technological innovations, that have left their marks on the landscape: Due to technological innovations, fewer people are needed to farm larger areas, i.e. the decline in proportion of population involved in agricultural land use surpasses by far the decline in use of farmland. Technology has greatly changed farming, resulting also in a change in landscape appreciation: Everything is done for speed now, so there is no time to watch and gaze around the countryside like we used to.

Climate change, finally, can be called a fifth basic factor determining landscape change. To date, the consequences are still minor, but chances are, that the future of cultural landscapes across Europe will be shaped by it, as changes in precipitation pattern and average temperature change the conditions for agriculture, but can also cause direct changes in landscape appearance, as in the case of melting glaciers in the Alps.

\section{Predictability of change}

Müller et al. (2014) state that "Land systems often undergo periods of nonlinear and abrupt change that invalidate predictions calibrated on past trends." They call for learning from past regime shifts and identifying early warning signs for future regime shifts. To what degree could this be done based on our results?

Our empirical results show infrastructural developments, (macro-) economic shifts and crises or also their end, as e.g. rapid development in the aftermath of World War Two, and increasing population numbers including the rise of new actors groups without farming background, which had the potential to trigger massive landscape changes. Other potential driving factors, such as the Common Agricultural Policy of the EU, did not show up consistently, but definitely played a role, e.g. as a driving force of land abandonment (Renwick et al. 2013). In general, specific, individual contexts determine if and how such developments have an impact on landscapes. An economic crisis triggering emigration might well lead to abandonment but the environmental conditions determine how rapidly fields and meadows turn into forests. In contrast, abandonment due to the conversion of a community structure from (subsistence) farming into commercial and industrial activities might lead to rapid changes. Such changes can be largely facilitated 
by infrastructural developments, enabling easy commuting to nearby centers.

Despite the detected communalities in driving forces, detecting early warning signs of future tipping points and regime shifts will remain highly challenging and trends will remain much easier to extrapolate than to predict. Maybe the aim has to be more modest: Interviews with local long-term residents may well help to assess upcoming changes in actor constellations, bearing the potential to expand the historical evaluation into an analysis of current and upcoming trends. The development of agricultural landscapes will for example take completely different trajectories if, to present two extremes, future farming is in the hands of investors buying up land to optimize its return in the current political context, not caring about local traditions and landscape characteristics at all, or if retired hobby farmers take care of the land, with the aim of maintaining a 'traditional' countryside without being dependent on income from products or subsidies.

\section{Conducting a comparative analysis}

Conducting a comparative analysis was the first methodological challenge addressed. The procedure developed allows for solid comparisons of case studies of landscape changes and related driving forces across very different landscapes and in very diverse political, historical and biogeographic contexts. Common criteria have to be defined regarding study site selection, sources used, methods applied and standards shared as expressed in mapping instructions for the digitalization process, common legend, and interview guidelines. Clearly, there are drawbacks and limitations arising from a comparative approach. For example, the need for a common legend for the LULC analysis comes at the expense of not being able to capture some site specific developments. To enable comparability but still capture the local characteristics, we applied a scaled legend, in which level one was fully comparable, and level two was optimized to best capture the local characteristics as depicted in the historical maps.

Combining mapped and perceived landscape changes

The second methodological challenge tackled was supplementing the LULC analysis with OHI-based perceived landscape changes, providing a more complete picture and increasing the validity of the findings for landscape changes. The OHIs provide a wealth of information on aspects of landscape dynamics, which are largely missing in map-based LULC analyses. They also might include information on hidden agendas and help to explain seemingly illogical changes (Antrop 2005). Often, interviewees directly involved in land use mention changes in land use intensity that might have either left visible traces in the landscape (such as the consequences of using larger machinery) or that were important for biodiversity without eminent landscape consequences (such as the intensification of use of grassland in Lenk, which today is cut four times a year instead of only twice).

Using OHIs and narratives becomes increasing popular in land change science (Young et al. 2006), be it in the form of expert-based country-level syntheses of land management shifts over 200 years (Rudbeck Jepsen et al. 2015), or oral history interviews with elderly inhabitants of a study landscape (as in the present example), whereas the interviewees are basically treated as local experts (e.g. Santana-Cordero et al. 2016). Asking such local experts regarding important landscape changes and related driving forces may point to events and circumstances that could otherwise be overseen.

Of course, the OHIs are based on perception and remembrance, and they are shaped by the daily proximity of the interviewees with their landscape: My older sister comes from Tartu and she doesn't recognise the home place at all; it is not the same village any more. I who live here everyday life I don't notice the changes so drastically". By looking at the map-analysis for his SM, another interviewee responded: These changes are real. But if you are living here you maybe do not really see it. It is a slow process. If you would go away and come back after 5 years it would be obvious. Consequently, OHIs with long-term residents who are/have been actively involved in land management might very well be-if carefully interpreted-the most suitable source to learn about land use practices, and to evaluate local perceptions of landscapes. But this does not make OHIs necessarily an optimal source for assessing actual changes of the landscape (see also Bieling 2013) and special care has to be given to how the interviewees are selected and that a well stratified and 
sufficiently large number of interviews is conducted (Davis and Wagner 2003).

\section{Conclusion}

Our study reflects the diversity and complexity of landscape change processes across Europe. This diversity, and the rather small number of SMs involved, makes it hard to determine common patterns or shared traits. The study nonetheless provides, a good overall picture of changes in European cultural landscapes and the related driving forces, thanks to two methodological achievements, i.e. conducting a comparative study and integrating information from mapped in addition to perceived landscape changes.

By designing the study for comparison from the beginning, we wanted to fill the gap between the single case studies and the meta-analyses, and address some of the challenges of syntheses in land change science, as described by Magliocca et al. (2015). Moreover, we feel that combining information on LULC changes as shown in maps and remote sensing data and landscape changes as perceived by the local population to be a mixed-method approach which deserves further application in that it considers and takes advantage of the complementarity and the specific strength and limitations of the various source types (e.g. Meyfroidt 2015).

The factors, which we determined to have left major traces in the landscape, i.e. access and infrastructure, political shifts, the labor market, technological innovations and climate change, will most likely continue to shape landscapes. Their predictability differs greatly: whereas changes in infrastructure are often the result of decades of planning and the effects of climate change also receive a lot of attention from the modeling community, shifts in political context or changes in the labor market due to economic developments might be hard, if not impossible to foresee. However this does not make them any less influential (e.g. Rudbeck Jepsen et al. 2015). Thus, land change science has to face an imbalance in the importance and predictability of the different forces potentially shaping the future of cultural landscapes.

Acknowledgements The research leading to these results has received funding from the European Community's Seventh Framework Program under Grant Agreement No. 603447 (Project HERCULES). This research contributes to the Program on Ecosystem Change and Society (www.pecs- science.org) and the Global Land Project (www.global landproject.org).

Open Access This article is distributed under the terms of the Creative Commons Attribution 4.0 International License (http:// creativecommons.org/licenses/by/4.0/), which permits unrestricted use, distribution, and reproduction in any medium, provided you give appropriate credit to the original author(s) and the source, provide a link to the Creative Commons license, and indicate if changes were made.

\section{References}

Antrop M (2000) Background concepts for integrated landscape analysis. Agric Ecosyst Environ 77:17-28

Antrop M (2005) Why landscapes of the past are important for future. Landsc Urban Plan 70:21-34

Baumann M, Kuemmerle T, Elbakidze M, Ozdogan M, Radeloff VC, Keuler NS, Prishchepov AV, Kruhlov I, Hostert P (2011) Patterns and drivers of post-socialist farmland abandonment in Western Ukraine. Land Use Policy 28:552-562

Bednarczyk B, Kaim D, Ostafin K (2016) Forest cover change or misinterpretation? On dependent and independent vectorisation approaches. Prace Geograficzne 146:19-30

Beilin R, Lindborg R, Stenseke M, Pereira HM, Llausàs A, Slätmo E, Cerqueira Y, Navarro L, Rodrigues P, Reichelt N, Munro N, Queiroz C (2014) Analysing how drivers of agricultural land abandonment affect biodiversity and cultural landscapes using case studies from Scandinavia, Iberia and Oceania. Land Use Policy 36:60-72

Bieling C (2013) Perceiving and responding to gradual landscape change at the community level: insights from a case study on agricultural abandonment in the Black Forest, Germany. Ecol Soc 18(2):36

Bürgi M, Gimmi U (2007) Three objectives of historical ecology: the case of litter collecting in Central European forests. Landscape Ecol 22:77-87

Bürgi M, Hersperger AM, Schneeberger N (2004) Driving forces of landscape change-current and new directions. Landscape Ecol 19:857-868

Bürgi M, Salzmann D, Gimmi U (2015) 264 years of change and persistence in an agrarian landscape: a case study from the Swiss lowlands. Landscape Ecol 30:1321-1333

Davis A, Wagner JR (2003) Who knows? On the importance of identifying "experts" when researching local ecological knowledge. Hum Ecol 31:463-489

ELC (2000) European landscape convention. Available at: http:// conventions.coe.int/Treaty/en/Treaties/html/176.htm

Feranec J, Hazeu G, Christensen S, Jaffrain G (2007) Corine land cover change detection in Europe (case studies of the Netherlands and Slovakia). Land Use Policy 24:234-247

Fogerty JE (2001) Oral history: a guide to its creation and use. In: Egan D, Howell EA (eds) The historical ecology handbook. Island Press, Washington DC, pp 101-120

Fuchs R, Herold M, Verburg PH, Clevers JGPW, Eberle J (2015) Gross changes in reconstructions of historic land cover/use for Europe between 1900 and 2010. Glob Change Biol 21:299-313 
Geist HJ, Lambin EF (2002) Proximate causes and underlying driving forces of tropical deforestation. Bioscience 52: 143-150

Kates RW, Turner BL, Clark WC (1990) The great transformation. In: Turner BL, Clark WC, Kates RW, Richards JF, Mathews JT, Meyer WB (eds) The earth as transformed by human action. Cambridge University Press, Cambridge, pp $1-17$

Lieskovský J, Bürgi M (submitted) Persistence in cultural landscapes-a pan-European analysis. Reg Environ Change (submitted)

Magliocca NR, Rudel TK, Verburg PH, McConnell WJ, Mertz O, Gerstner K, Heinimann A, Ellis EC (2015) Synthesis in land change science: methodological patterns, challenges, and guidelines. Reg Environ Change 15:211-226

Marcucci DJ (2000) Landscape history as a planning tool. Landsc Urban Plan 49:67-81

Meyfroidt P (2015) Approaches and terminology for causal analysis in land system science. J Land Use Sci. doi:10. 1080/1747423X.2015.1117530

Müller D, Sun Z, Vongvisouk T, Pflugmacher D, Xu J, Mertz O (2014) Regime shifts limit the predactability of land-system change. Glob Environ Change 28:75-83

Munteanu C, Kuemmerle T, Boltiziar M, Butsic V, Gimmi U, Halada L, Kaim D, Király G, Konkoly-Gyruó É, Kozak J, Lieskovský J, Mojses M, Müller D, Ostafin K, Ostapovicz K, Shandra O, Stych P, Walker S, Radeloff VC (2014) Forest and agricultural land change in the Carpathian region - a meta-analysis of long-term patterns and drivers of change. Land Use Policy 38:685-697

Patru-Stupariu I, Tudor CA, Stupariu MS, Buttler A, Peringer A (2016) Landscape persistence and stakeholder perspectives: the case of Romania's Carpathians. Appl Geogr 69:87-98

Plieninger T, Draux H, Fagerholm N, Bieling C, Bürgi M, Kizos T, Kuemmerle T, Primdahl J, Verburg PH (2016) The driving forces of landscape change in Europe: a systematic review of the evidence. Land Use Policy 57:204-214

Renwick A, Jansson T, Verburg PH, Revoredo-Giha C, Britz W, Gocht A, McCracken D (2013) Policy reform and agricultural land abandonment in the EU. Land Use Policy 30:446-457

Rhemtulla JM, Mladenoff DJ (2007) Why history matters in landscape ecology. Landscape Ecol 22:1-3

Rindfuss RR, Stern PC (1998) Linking remote sensing and social science: the need and the challenges. In: Liverman D, Moran EF, Rindfuss RR, Stern PC (eds) People and pixels: linking remote sensing and social science. National Academy Press, Washington DC, pp 1-27

Rindfuss RR, Walsh SJ, Turner BL II, Fox J, Mishra V (2004) Developing a science of land change: challenges and methodological issues. PNAS 101:13976-13981

Rudbeck Jepsen M, Kuemmerle T, Müller D, Erb KH, Verburg PH, Haberl H, Vesterager JP, Andric M, Antrop M,
Austrheim G Björn I, Bondeau A, Bürgi M, Bryson J, Caspar G, Cassar LF, Conrad E, Chromy P, Daugirdas V, Van Eetvelde V, Elena-Rossello R, Gimmi U, Izakovicova Z, Jancak V, Jansson U, Kladnik D, Kozak J, KonkolyGyuro E, Krausmann F (2015) Transition in European land management regimes between 1800 and 2010. Land Use Policy 49:53-64

Santana-Cordero AM, Monteiro-Quintana ML, HernandezCalvento L (2016) Reconstruction of the land uses that led to the termination of an arid coastal dune system: the case of the Guanarteme dune system (Canary Islands, Spain), 1834-2012. Land Use Policy 55:73-85

Schneeberger N, Bürgi M, Kienast F (2007) Rates of landscape change at the northern fringe of the Swiss Alps: historical and recent tendencies. Landsc Urban Plan 80:127-136

Sooväli H, Palang H, Kaur E, Peil T, Vermandere I (2003) Combining approaches in landscape research. The case of Saaremaa, Estonia. In: Palang H, Fry G (eds) Landscape interfaces: cultural heritage in changing landscapes. Landscape Series 1, Springer, pp 357-374

Steiner F (2016) Human ecology. How nature and culture shape our world. Island Press, Washington DC

Terres JM, Scacchiafichi LN, Wania A, Ambar M, Anguiano E, Buckwell A, Coppola A, Gocht A, Källström HN, Pointereau P, Strijker D, Visek L, Vranken L, Zobena A (2015) Farmland abandonment in Europe: identification of drivers, indicators, and development of a composite indicator of risk. Land Use Policy 49:20-34

Turner BL, Clark WC, Kates RW, Richards JF, Mathews JT, Meyer WB (eds) (1990) The earth as transformed by human action: global and regional changes in the biosphere over the past 300 years. Cambridge University Press, Cambridge

van Vliet J, de Groot HLF, Rietveld P, Verburg PH (2015) Manifestations and underlying drivers of agricultural land use change in Europe. Landsc Urban Plan 133:24-36

Wierling D (2003) Oral history. In: Maurer M (ed) Aufriss der Historischen Wissenschaften, Bd 7: Neue Themen und Methoden der Geschichtswissenschaft. Reclam, Stuttgart, pp 81-151

Wirth E (1969) Zum Problem einer allgemeinen Kulturgeographie: raummodelle-kulturgeographische Kräftelehre-raumrelevante Prozesse-Kategorien. Erde 2-4: 155-193

Wood R, Handley J (2001) Landscape dynamics and the management of change. Landsc Res 26:45-54

Yaeger CD, Steiger T (2013) Applied geography in a digital age: the case for mixed methods. Appl Geogr 39:1-4

Young OR, Lambin EF, Alcock F, Haberl H, Karlsson SI, McConnell WJ, Myint T, Pahl-Wostl C, Polsky C, Ramakrishnan PS, Schroeder H, Scouvart M, Verburg PH (2006) A portfolio approach to analysing complex humanenvironment interactions: institutions and land change. Ecol Soc 11(2):31 